\title{
ISOLASI DAN UJI AKTIVITAS ANTIBAKTERI DARI BAKTERI YANG BERASOSIASI DENGAN ALGA Turbinaria ornata (Turner) J. Agardh SERTA IDENTIFIKASI SECARA BIOKIMIA.
}

\author{
Cicilia Kosasi $^{1)}$,Widya A. Lolo ${ }^{1)}$, Sri Sedewi ${ }^{1)}$ \\ ${ }^{1)}$ Program Studi Farmasi FMIPA UNSRAT Manado, 95115
}

\begin{abstract}
Algae are a place to live for various microorganisms' symbiosis with them, and some of them were known to be used as antibacterial. This study aims to determine the antibacterial activity of associated bacteria isolates from Turbinaria ornata algae obtained from the Bay of Manado against Staphylococcus aureus and Escherichia coli bacteria. In the course of testing the isolation and purification of symbiotic bacteria from Turbinaria ornata algae, then antibacterial activity was testing using agar diffusion method, then gram staining and biochemical tests were carried out including motility test, $\mathrm{H}_{2} \mathrm{~S}$ tets, carbohydrate fermentation test, citrate test, lysine test, indole test and catalase test. The result showed that there were 3 bacterial isolates, which had antibacterial activity in medium category against S.aureus and E.coli bacteria. Based on the results of biochemical identification, the isolates that have the greatest inhibitory power, they were thought to belong to genus Bacillus and the genus Yersinia.
\end{abstract}

Keywords : Antibacterial, Symbionic bacteria, Turbinaria ornata(Turner) J. Agardh.

\begin{abstract}
ABSTRAK
Alga merupakan tempat hidup berbagai mikroorganisme yang bersimbiosis dengannya, dan beberapa dari spesies alga diketahui sering dimanfaatkan salah satunya sebagai antibakteri. Penelitian ini bertujuan untuk mengetahui adanya aktivitas antibakteri dari isolat bakteri yang berasosiasi dengan alga Turbinaria ornata yang diperoleh dari Teluk Manado terhadap bakteri Staphylococcus aureus dan Escherichia coli. Dalam pengujian dilakukan isolasi dan purfifikasi bakteri simbion dari alga Turbinari ornata, kemudian dilakukan pengujian aktivitas antibakteri menggunakan metode difusi agar, selanjutnya silakukan pewarnaan gram dan uji biokimia meliputi uji motilitas, uji $\mathrm{H}_{2} \mathrm{~S}$, uji fermentasi karbohidrat, uji sitrat, uji lisin, uji indol dan uji katalase. Hasil penelitian menunjukkan bahwa terdapat 3 isolat bakteri yang mempunyai daya aktivitas antibakteri dalam kategori sedang terhadap bakteri S. aureus dan E. coli. Berdasarkan hasil identifikasi secara biokimia isolat yang mempunyai daya hambat paling besar diduga termasuk dalam genus Bacillus dan genus Yersinia.
\end{abstract}

Kata kunci : Antibakteri, Bakteri simbion, Turbinaria ornata (Turner) J. Agardh. 


\section{PENDAHULUAN}

Salah satu makhluk hidup yang tumbuh dan berkembang di laut adalah alga. Ditinjau secara biologi, alga merupakan kelompok tumbuhan berklorofil yang terdiri dari satu atau banyak sel dan berbentuk koloni (Satari, 1996). Obat baru yang berasal dari biota laut, saat ini menjadi perhatian para pengembangan peneliti dikarenakan tingginya keanekaragaman hayati laut serta keunikan struktur metabolit sekunder yang dihasilkannya. Senyawa bioaktif yang berasal dari laut dapat menjadi alternatif dalam pengembangan obat antibakteri yang baru (Harmawan et al., 2012).

Turbinaria ornata (Turner) J. Agardh adalah salah satu jenis rumput laut cokelat yang menghasilkan alginat (Laksanawati et al., 2017). Ekstrak rumput laut dari Turbinaria ornata (Turner) J. Agardh memiliki aktivitas antibakteri yang berbeda dan menunjukkan metabolit sekunder yang bervariasi dalam melawan bakteri gram negative dan bakteri gram positif jika dibandingkan dengan standar ampisilin. Alga coklat seperti Turbinaria ornata (Turner) J. Agardh aktif terhadap beberapa bakteri patogen antara lain seperti Bacillus subtilis, Escherichia coli, Klebsiella pneumoniae, Proteus vulgaris, Pseudomonas aeruginosa, Shigella flexneri dan Staphylococcus aureus. (Vijayabaskar et al., 2011).

Berdasarkan latar belakang di atas maka perlu dilakukan penelitian untuk mengetahui aktivitas antibakteri simbion isolat dari alga Turbinaria ornata (Turner) J. Agardh terhadap bakteri Escherichia coli dan Staphylococcus aureus. Selain itu, untuk mengetahui spesies bakteri endofit yang memiliki daya antibakteri terbesar maka dilakukan analisis secara biokimia.

\section{METODE PENELITIAN}

\section{Alat}

Alat yang digunakan dalam penelitian ini yaitu gunting, alat Diving, cooling box, zipper bag, kamera bawah laut (Xiomi), erlenmeyer (Iwaki ST Pyrex), gelas ukur $\mathrm{mL}$ (Iwaki ST Pyrex), tabung reaksi, raktabung reaksi, pipet tetes, timbangan analitik
(ADAM), lumpang dan alu, cawan petri (Iwaki ST Pyrex), jarum ose, pinset, rotary shaker incubator (Infors HT), bunsen, lemari pendingin, laminar air flow (Biotek), autoklaf (ALP), mikropipet (Ecopipette), tip, L-glass, jangka sorong, kertas label,plastik wrap, aluminium foil, tisu,kapas, kasa, mikroskop cahaya, kaca objek, alat fotografi.

Bahan

Bahan-bahan yang digunakan yaitu alga Turbinaria ornata (Turner) J. Agardh bakteri uji Escherichia coli dan Staphylococcus aureus, aquades, etanol $70 \%$, etanol $95 \%$, $\mathrm{NaCl} 0.9 \%$, Natrium Hipoklorit $(\mathrm{NaOCl})$ 5,25\%, media Nutrient Agar, media Nutrient Broth, media Simmons citrate Agar, media Lysin Iron Agar, media Triple Sugar Iron Agar, paper disc Kloramfenikol, kristal violet, lugol, larutan safranin, reagen Covac's, masker dan sarung tangan.

\section{Prosedur Penelitian}

\section{Sterilisasi Alat}

Alat-alat gelas disterilkan dengan autoklaf pada suhu $121^{\circ} \mathrm{C}$ selama \pm 15 menit pinset, L-glass, dan jarum ose di bakar di atas api langsung (Pembakar spritus) (Waluyo,2014).

\section{Pengambilan Sampel}

Sampel alga diambil dari perairan Teluk Manado menggunakan alat bantu (Masker dan Snorkel). Sampel difoto dengan kamera bawah laut, diambil, lalu dimasukkan ke dalam zipper bag, kemudian dibawa langsung ke Laboratorium Mikrobiologi Farmasi Program Studi Farmasi dan untuk identifikasi sampel, sampel dibawa ke laboratorium Taksonomi Biologi Universitas Sam Ratulangi.

\section{Pembuatan Media \\ 1.Media Pertumbuhan}

Media dibuat dengan menimbang sebanyak 6,16 gram NA kemudian dimasukkan ke dalam Erlenmeyer dan dilarutkan dengan aquades sebanyak $220 \mathrm{~mL}$ (28 gram/ $1000 \mathrm{~mL})$. Selanjutnya, dihomogenkan dengan magnetic stirrer di atas hot plate. Media yang telah homogen kemudian disterilkan dalam autoklaf pada suhu $\pm 121^{\circ} \mathrm{C}$. Media kemudian dituang kedalam 11 cawan petri masing-masing 
sebanyak $20 \mathrm{~mL}$ dan untuk tabung reaksi (sebagai agar miring) dimasukkan pada 9 tabung reaksi masing-masing sebanyak $10 \mathrm{~mL}$ media NA. Media yang telah padat ditutup dengan kapas agar bebas dari kontaminan. Media ini digunakan untuk beberapa keperluan yaitu penanaman awal bakteri simbion dari sampel yang telah diencerkan secara berseri, isolasi bakteri, kultur stock isolat bakteri simbion endofit, dan pengujian aktivitas antibakteri (Volk dan wheeler, 1993).

\section{Media Pembenihan}

Media dibuat dengan menimbang NB sebanyak 0,72 gram kemudian dimasukkan ke dalam Erlenmeyer dan dilarutkan dengan aquades hingga $90 \mathrm{~mL}$ (8 gram/ $1000 \mathrm{~mL}$ ). Selanjutnya, dihomogenkan dengan magnetic stirrer diatas hot plate. Media yang telah homogen kemudian disterilkan dalam autoklaf pada suhu $121^{\circ} \mathrm{C}$ selama 15 menit, kemudian dibiarkan hingga sedikit dingin. Media kemudian dituang ke dalam Erlenmeyer sebanyak $10 \mathrm{~mL}$. Media ini digunakan untuk inokulasi bakteri simbion untuk pengujian aktivitas antibakteri (Hudayanti, 2004).

\section{Isolasi Dan Purifikasi Bakteri Simbion}

Penanaman bakteri simbion yang bersimbiosis dengan alga dilakukan dengan metode sebaran menurut Madigan (2012). 1 gram sampel alga yang telah disterilisasi permukaannya dihancurkan dengan cara digerus dengan lumpang dan alu sampai halus. Selanjutnya, kedalam 1 gram sampel ditambahkan NaCL sampai $10 \mathrm{~mL}$ yang akan digunakan untuk pengenceran bertingkat sehingga diperoleh pengenceran sampel sebesar $11^{-0}$. Pengenceran bertingkat selanjutnya dilakukan untuk seri $110^{-1}$, $110^{-2}, 110^{-3}$ dan $110^{-4}$ Dari masingmasing seri kemudian diambil $100 \mu \mathrm{L}$ dan disebarkan ke dalam cawan petri steril yang berisi media NA dan diinkubasi dalam inkubator pada suhu $37^{\circ} \mathrm{C}$ selama $1 \times 24$ jam. Koloni bakteri simbion yang tumbuh diamati warna, bentuk,elevasi, tepian dan ukurannya. Koloni-koloni bakteri dipisahkan dengan jarum ose berdasarkan perbedaan karakteristik makroskopik dan mikroskopiknya pada media NA baru dalam cawan petri dan diinkubasi pada suhu $37^{\circ} \mathrm{C}$ selama 24 jam. Isolat yang telah murni diambil menggunakan jarum öse untuk dipindahkan ke media agar miring untuk mendapatkan isolat bakteri dengan membentuk garis zig-zag selanjutnya diinkubasi dalam inkubator pada suhu $37^{\circ} \mathrm{C}$ selama $\pm 1 \times 24$ jam (Vandepitte, 2010).

\section{Pengujian Aktivitas Antibakteri}

\section{Pembuatan Larutan Mc. Farland 0.5}

Larutan $\mathrm{H}_{2} \mathrm{SO}_{4} 1 \%$ sebanyak $9,95 \mathrm{~mL}$ dicampurkan dengan larutan $\mathrm{BaCl}_{2} \cdot 2 \mathrm{H}_{2} \mathrm{O}$ $1,75 \%$ sebanyak $0,05 \mathrm{~mL}$ dalam erlenmeyer. Kemudian dikocok sampai terbentuk larutan yang keruh. Kekeruhan ini dipakai sebagai standar kekeruhan suspensi bakteri uji (Victor, 1980).

\section{Pembuatan Suspensi Bakteri Uji}

Bakteri uji berupa Eshcerichia coli dan Staphylococcus aureus yang telah diinokulasi diambil dengan jarum ose steril kemudian disuspensikan kedalam tabung yang berisi 5 $\mathrm{mL}$ larutan $\mathrm{NaCl}$ 0.9\% hingga diperoleh kekeruhan yang sama dengan standar kekeruhan larutan Mc.Farland 0.5. Suspensi bakteri kemudian dipipet sebanyak $100 \mu \mathrm{L}$ dan dituangkan media NA yang telah memadat (Ngajow et al..2013).

\section{Penyiapan bakteri simbion}

Satu ose isolat bakteri alga diinokulasi kedalam $10 \mathrm{~mL}$ media cair NB dan diinkubasi selama 24 jam dalam Incubator dengan suhu $37^{\circ} \mathrm{C}$. Masing-masing koloni bakteri simbion dalam media cair kemudian dipindahkan ke dalam tabung sentrifuge dan disentrifugasi dengan kecepatan 3000 rpm selama 30 menit. Supernatant yang terbentuk diambil untuk pengujian aktivitas antibakteri (Hudayanti, 2004).

\section{Pengujian aktivitas antibakteri}

Metode yang digunakan yaitu Metode Difusi (Disc Diffusion Kirby and Bauer). Pengujian aktivitas antimikroba ini cakram (paper disc) yang digunakan berukuran $6 \mathrm{~mm}$ dengan daya serap $50 \mu \mathrm{L}$ pada tiap cakram. Diinokulasi suspensi bakteri uji diatas media yang telah memadat. Kertas cakram yang telah direndam dengan isolat bakteri alga diinokulasikan diatas media yang telah berisi 
bakteri uji, kemudian diinkubasi selama $1 \mathrm{x}$ 24 jam (Fardiaz, 1987).

\section{5. pengukuran zona hambat}

Pengamatan dilakukan terhadap zona bening yang terbentuk disekitar kertas cakram setelah masa inkubasi yaitu 1x24 jam. Diameter zona bening ini kemudian diukur dengan menggunakan jangka sorong dengan ketelitian 0,05 mm (Ortez, 2005). Diameter zona bening yang terukur dikategorikan kekuatan daya antibakterinya berdasarkan penggolongan (Davis et al, 1971).

\section{Uji Morfologi}

Uji morfologi dilakukan dengan pewarnaan Gram. Biakan bakteri pada media miring diambil dengan menggunakan jarum ose, kemudian ditotol pada bagian tengah kaca objek sampai merata. Preparat selanjutnya difiksasi diatas lampu bunsen. Selanjutnya preparat diwarnai dengan kristal violet selama 1 menit. Kristal violet dicuci pada air mengalir. Preparat kembali diwarnai dengan larutan lugol dan didiamkan selama 1 menit. Larutan lugol dicuci dengan alkohol 96\% dan dicuci pada air mengalir. Selanjutnya preparat diwarnai dengan safranin dan didiamkan selama 1 menit. Preparat dicuci pada air mengalir, dikeringkan dan diperiksa dengan mikroskop dengan menambahkan minyak imersi (Macfaddin, 2000).

\section{Uji Fisiologi}

Uji fisiologi dilakukan dengan uji motilitas yang bertujuan untuk mengetahui pergerakan bakteri uji. Prosedur kerja: media nutrient agar ditimbang sebanyak 0,58 gram kemudian dimasukkan ke dalam erlenmeyer dan dilarutkan bersama dengan aquades sebanyak $21 \mathrm{~mL}$. Media disterilisasi pada suhu $121^{\circ} \mathrm{C}$ selama 15 menit. Selanjutnya media dituangkan pada masing-masing tabung reaksi sebanyak $7 \mathrm{~mL}$ kemudian didinginkan. Setelah memadat, kultur bakteri diinokulasikan dengan tusukan jarum ose sampai dasar media. Diinkubasi pada suhu $37^{\circ} \mathrm{C}$ selama 24 jam. Hasil positif bila terlihat adanya pertumbuhan melebar dari bekas tusukan jarum ose (Talaro, 2008).

\section{Uji Biokimia}

\section{Uji $\mathrm{H}_{2} \mathrm{~S}$}

Media triple sugar iron agar (TSIA) ditimbang sebanyak 4,55 gram, kemudian dimasukkan ke dalam erlenmeyer dan dilarutkan bersama dengan aquades sebanyak $70 \mathrm{~mL}$. Media disterilisasi pada suhu $121^{\circ} \mathrm{C}$ selama 15 menit. Selanjutnya media dituangkan pada masing-masing tabung reaksi sebanyak $7 \mathrm{~mL}$ dan dimiringkan sampai memadat pada kemiringan $30^{\circ}$. Setelah media memadat, secara aseptik isolat bakteri diinokulasikan dengan jarum ose dengan cara ditusuk pada bagian tengah sampai kedalaman $3 / 4$ bagian dari permukaan media dan kemudian digores pada bagian miring dari media. Selanjutnya diinkubasi pada suhu $37^{\circ} \mathrm{C}$ selama $1 \times 24$ jam. Hasil positif bila terbentuk endapan berwarna hitam pada bagian bawah media yang berarti bakteri dapat membentuk $\mathrm{H}_{2} \mathrm{~S}$ (Lay, 1994).

\section{Uji Fermentasi Karbohidrat}

Media TSIA dibuat seperti pada uji $\mathrm{H}_{2} \mathrm{~S}$. Media disterilisasi pada suhu $121{ }^{\circ} \mathrm{C}$ selama 15 menit. Selanjutnya media dituangkan pada masing-masing tabung reaksi sebanyak $7 \mathrm{~mL}$ dan dimiringkan sampai memadat. Setelah media memadat, secara aseptik isolat bakteri diinokulasikan dengan jarum ose dengan cara ditusuk pada bagian tengah sampai kedalaman $3 / 4$ bagian dari permukaan media dan kemudian digores pada bagian miring dari media. Selanjutnya diinkubasi pada suhu $37^{\circ} \mathrm{C}$ selama $1 \times 24$ jam. Hasil positif bila terjadi pembentukan asam dan pembentukan gas. Pembentukan asam terlihat sebagai perubahan warna substrat karbohidrat dari warna merah menjadi warna kuning. Pembentukan gas terjadi didasar media yang ditandai dengan adanya ruang kosong didasar media (Cappuccino dan Sherman, 1992).

\section{Uji Sitrat}

Media Simmons's citrate agar ditimbang sebanyak 0,50 gram kemudian dimasukkan ke dalam erlenmeyer dan dilarutkan bersama dengan aquades sebanyak $21 \mathrm{~mL}$. Media disterilisasi pada suhu $121^{\circ} \mathrm{C}$ selama 15 menit. Selanjutnya media dituangkan pada masing-masing tabung reaksi sebanyak $7 \mathrm{~mL}$ dan dimiringkan sampai memadat pada kemiringan $30^{\circ}$. Setelah media memadat, secara aseptik isolat bakteri 
diinokulasikan dengan jarum ose dengan cara ditusuk pada bagian tengah sampai kedalaman $3 / 4$ bagian dari permukaan media dan kemudian digores pada bagian miring dari media. Selanjutnya diinkubasi pada suhu $37^{\circ} \mathrm{C}$ selama $1 \times 24$ jam. Hasil positif bila terjadi perubahan warna dari warna hijau tua menjadi warna biru (Cappuccino dan Sherman, 1992).

\section{Uji Lisin}

Media lysine iron agar ditimbang sebanyak 0,72 gram kemudian dimasukkan ke dalam erlenmeyer dan dilarutkan bersama dengan aquades sebanyak $21 \mathrm{~mL}$. Media disterilisasi pada suhu $121^{\circ} \mathrm{C}$ selama 15 menit. Selanjutnya media dituangkan pada masing-masing tabung reaksi sebanyak $7 \mathrm{~mL}$ dan dimiringkan sampai memadat pada kemiringan $30^{\circ}$. Setelah media memadat, secara aseptik isolat bakteri diinokulasikan dengan jarum ose dengan cara ditusuk pada bagian tengah sampai kedalaman $3 / 4$ bagian dari permukaan media dan kemudian digores pada bagian miring dari media. Selanjutnya diinkubasi pada suhu $37^{\circ} \mathrm{C}$ selama $1 \times 24$ jam. Hasil positif bila terjadi perubahan warna pada media menjadi warna lembayung (violet) (Cappuccino dan Sherman, 1992).

\section{Uji Indol}

Media dibuat dengan menimbang NA sebanyak $0,59 \mathrm{~g}$ dan dilarutkan dalam $21 \mathrm{~mL}$ aquadest. Media yang telah homogen disterilkan di dalam autoklaf pada suhu $121^{\circ} \mathrm{C}$ selama 15 menit, kemudian dibiarkan untuk mendinginkan pada suhu ruangan sampai beberapa saat. Media kemudian dituang ke dalam tabung reaksi masing-masing sebanyak $7 \mathrm{~mL}$. Isolat diinokulasikan dengan koloni biakan yang berasal dari masing-masing agar miring dengan cara ditusukkan jarum sedalam $3 / 4$ bagian. Diinkubasi pada suhu $37^{\circ} \mathrm{C}$ selama $1 \times 24$ jam, dengan menambahkan 0,2-0,3 ml reagen covac's. Hasil positif apabila kultur bewarna merah pada saat penambahan reagen (Lay, 1994).

\section{Uji Katalase}

Media nutrient broth ditimbang sebanyak 0,17 gram kemudian dimasukkan ke dalam erlenmeyer dan dilarutkan bersama dengan aquades sebanyak $21 \mathrm{~mL}$. Media disterilisasi pada suhu $121^{\circ} \mathrm{C}$ selama 15 menit. Selanjutnya media dituangkan pada masing-masing tabung reaksi sebanyak $7 \mathrm{~mL}$. Kemudian secara aseptik isolat bakteri diinokulasi ke dalam media. Selanjutnya diinkubasi pada suhu $37^{\circ} \mathrm{C}$ selama $1 \times 24$ jam. Kedalam tabung reaksi ditambahkan 5 tetes $\mathrm{H}_{2} \mathrm{O}_{2}$. Hasil positif bila terjadi pembentukan gelembung udara (Cappuccino dan Sherman, 1992).

\section{HASIL DAN PEMBAHASAN 1.Determinasi Sampel}

Alga Turbinaria ornata (Turner) J. Agardh yang telah diperoleh dari perairan Teluk Manado, Sulawesi Utara. Sampel dideterminasi di Laboratorium Taksonomi Biologi Program Studi Biologi untuk mengetahui jenis sampel yang diambil. Hasil identifikasi menunjukkan bahwa sampel yang digunakan adalah alga Turbinaria ornata (Turner) J. Agardh.

\section{Isolasi dan Purifikasi Bakteri simbion}

Pada penelitian ini, Setelah dilakukan penanaman bakteri yang berasosiasi dengan alga Turbinaria ornata pada media NA Plate, koloni bakteri yang berasosiasi dengan alga yang tumbuh diamati perbedaan karakterisitik secara makroskopik. Kemudian pengamatan setelah dilakukan penanaman selama 1x24 jam, isolat bakteri dari alga Turbinaria ornata yang tumbuh terlihat seperti bercak-bercak halus yang berwarna putih. Selanjutnya pemurnian isolat bakteri yang tumbuh dilakukan dengan cara diinokulasikan kembali menggunakan jarum ose ke media NA yang baru dan diinkubasi selama $1 \times 24$ jam pada suhu ruangan. Hal ini bertujuan untuk memisahkan koloni-koloni bakteri berdasarkan bentuk, warnah, dan ukuran agar didapatkan isolat bakteri dengan karakteristik secara makroskopik yang mempunyai morfologi yang sama sehingga dapat disebut sebagai isolat murni bakteri.

\section{Kultur Cair}

Pada penelitian ini, masing-masing isolat bakteri murni dikultur atau dibiakkan pada media cair menggunakan media NB (Nutrient Broth), dengan metode shaker pada suhu $37^{\circ} \mathrm{C}$ dengan kecepatan $150 \mathrm{rpm}$, hal ini 
bertujuan agar semua nutrisi yang dikandung dalam medium dapat digunakan oleh bakteri secara optimal sebagai bahan untuk proses metabolismenya sehingga senyawa antibakteri dapat dihasilkan dengan optimal. Setelah dilakukan pengamatan, hasil dari pembiakkan bakteri pada media cair NB yang diinkubasi selama 1x24 jam, terlihat media berubah menjadi keruh, hasil dari pembiakkan ini yang nantinya akan digunakan dalam pengujian aktivitas antibakteri.

\section{Pengujian Aktivitas Antibakteri}

Pada pengujian ini digunakan kontrol positif dan negatif. Penggunaan kontrol positif berfungsi sebagai kontrol dari zat uji, dengan membandingkan diameter daerah hambat yang terbentuk (Dwijendra, 2014). Sedangkan tujuan penggunaan kontrol negatif agar dapat mengetahui ada tidaknya pengaruh pelarut terhadap pertumbuhan mikroba uji, sehingga dapat dipastikan bahwa aktivitas yang ditunjukkan oleh ekstrak ialah senyawa yang terkandung dalam sampel bukan berasal dari pelarut yang digunakan. Dalam penelitian ini, pelarut $\mathrm{NaCL}$ digunakan sebagai kontrol negatif.

Pada pengujian ini, isolat bakteri dari sampel Turbinaria ornata yang akan diuji aktivitas antibakteri ada 9 isolat bakteri, dari masing-masing isolat bakteri tersebut dilakukan pengulangan sebanyak $3 \mathrm{kali}$, dari pengulangan ini dilakukan untuk lebih mengakuratkan hasil yang akan diperoleh. Hasil yang diperoleh ini menunjukan bahwa adanya kepekaan bakteri terhadap isolat dari alga Turbinaria ornata dan antibiotik yang digunakan sebagai kontrol positif, dari beberapa isolat bakteri yang diuji menunjukkan terbentuknya daya hambat/zona bening disekeliling kertas cakram (paper disc) yang berukuran $5 \mathrm{~mm}$, Pengamatan dilakukan setelah di inkubasi pada suhu $37^{\circ} \mathrm{C}$ selam 1x24 jam.

Pengujian aktivitas antibakteri untuk setiap isolat bakteri dari sampel Turbinaria ornata menggunakan kertas cakram (paper disc), pengujian dilakukan terhadap bakteri uji Eschericia coli dan Staphylococcus aureus. Hasil yang didapat dari pengukuran rata-rata diameter zona bening yang terbentuk disekitar cakram dari isolat bakteri sampel Turbinaria ornata terhadap bakteri uji Staphylococcus aureus dan Eschericia coli ditunjukan pada Tabel dibawah ini.

Tabel1. Hasil uji aktivitas antibakteri

\begin{tabular}{l|l|l|c|c|c}
\hline Bakteri Uji & \multicolumn{5}{|c}{ Diameter Zona Bening (mm) } \\
\hline & $\mathrm{K}+$ & $\mathrm{K}-$ & $\mathrm{C}_{1}$ & $\mathrm{C}_{2}$ & $\mathrm{C}_{3}$ \\
\hline S. aureus & 16,00 & 0 & 6,67 & 6,67 & 7,33 \\
\hline E. coli & 15,00 & 0 & 6,67 & 6,33 & 6,67 \\
\hline
\end{tabular}

Pada pengujian ini, kontrol positif menggunakan antibiotik kloramfenikol dimana antibiotik adalah suatu senyawa kimia yang dapat menghambat proses penting dalam kehidupan suatu mikroorganisme (Soekardjo dan Siswandono, 2000). Kloramfenikol atau Kloramisetin adalah antibiotik yang mempunyai spektrum luas yang dapat digunakan untuk melawan infeksi yang disebabkan oleh beberapa jenis bakteri grampositif dan bakteri gram-negatif. Kloramfenikol mempunyai khasiat bakterisid (Sumardjo, 2009). Kontrol positif berfungsi sebagai pembanding antara antibakteri yang sudah terstandarisasi dengan sampel Turbinaria ornata. Kemudian kontrol negatif yang digunakan yaitu $\mathrm{NaCL}$, fungsi dari kontrol negatif sendiri yaitu untuk mengetahui ada tidaknya pengaruh pelarut terhadap pertumbuhan bakteri, sehingga dapat diketahui bahwa aktivitas antibakteri yang dihasilkan bukan berasal dari pelarut yang digunakan melainkan berasal dari aktivitas senyawa yang terdapat dalam sampel Turbinaria ornata (Turner) J. Agardh.

\section{Uji morfologi, fisiologi dan uji biokimia}

Pengujian ini, dilakukan dengan uji morfologi atau identifikasi bakteri yang diawali dengan pewarnaan Gram. Pengamatan tentang karakteristik morfologi koloni bakteri perlu dilakukan agar mempermudah proses identifikasi jenis dari isolate bakteri (lenni et al.,2011). Uji pewarnaan Gram dilakukan pada setiap isolat bakteri dari sampel Turbinaria ornata yang memiliki daya hambat terbesar, dari beberapa isolat bakteri tersebut dilakukan pengujian morfologi atau pewarnan gram yang bertujuan untuk mengetahui bentuk-bentuk bakteri (basil, kokus atau spiril), penentuan bakteri jenis 
Gram positif atau Gram negatif pada saat pengamatan di mikroskop.

Hasil pengujian morfologi atau pewarnaan Gram pada setiap isolat bakteri bervariasi dimana untuk isolat bakteri diberikan kode $\mathrm{C}_{1}, \mathrm{C}_{2}$ dan $\mathrm{C}_{3}$ dari ketiga isolat bakteri tersebut untuk kode isolat $\mathrm{C}_{3}$ menunjukkan hasil yang berwarna ungu, dan untuk kode isolat $\mathrm{C}_{1}, \mathrm{C}_{2}$ menunjukkan hasil yang berwarna merah muda. Beberapa isolat bakteri yang diuji menunjukkan adanya bakteri gram negatif dan bakteri gram positif yang berperan dalam aktivitas antibakteri dari sampel Turbinaria ornata. Menurut Taslihan et al. (2001), bahwa warna bakteri terlihat merah, artinya bakteri bersifat gram negatif karena sel bakteri tidak menyerap cat utama (Gram's iodin) dengan kuat sehingga terbilas dengan alcohol dan terwarnai dengan cat pelawan. Dan bakteri gram positif pada pewarnaan gram menunjukkan hasil yang berwarna ungu atau birukarena kompleks zat warna Kristal violet-yodium tetap dipertahankan meskipun diberi larutan pemucat aseton alcohol (lay, 1994). Bakteri terdiri dari tiga bentuk dasar yaitu bentuk bulat atau kokus, bentuk batang atau basil, dan bentuk spiral (Dwidjoseputro, 1985), dalam penelitian ini ditemukan 1 bentuk bakteri yaitu bentuk batang atau basil. Hasilnya dapat dilihat pada tabel dibawah ini. Tabel 2. Hasil Uji Morfologi dan fisiologi

\begin{tabular}{lccc}
\hline \multirow{2}{*}{$\begin{array}{l}\text { Kode } \\
\text { Isolat }\end{array}$} & \multicolumn{2}{l}{ Uji Morfologi } & \multicolumn{2}{l}{$\begin{array}{l}\text { Uji } \\
\text { Fisologi }\end{array}$} \\
\cline { 2 - 4 } & Pewarnaan Gram & \\
\cline { 2 - 4 } & Bentuk & Warna & $\begin{array}{c}\text { Uji } \\
\text { Motilitas }\end{array}$ \\
\hline $\mathbf{C}_{\mathbf{1}}$ & Basil & $\begin{array}{c}\text { Merah } \\
\text { muda }\end{array}$ & - \\
\hline $\mathbf{C}_{\mathbf{2}}$ & Basil & $\begin{array}{c}\text { Merah } \\
\text { muda }\end{array}$ & - \\
\hline $\mathbf{C}_{\mathbf{3}}$ & Basil & Ungu & - \\
\hline
\end{tabular}

Data uji biokimia, uji morfologi dan uji fisiologi yang diperoleh dibandingkan dengan buku Bergey's Manual Determinative of Bacteriology. Hasil uji biokimia dapat dilihat pada Tabel dibawah ini.

Tabel 3. Hasil Uji Biokimia

\begin{tabular}{llllll}
\hline \multicolumn{5}{c}{ Uji Biokimia } \\
\hline Uji & Uji & Uji & Uji & Uji & Uji \\
$\mathrm{H}_{2} \mathrm{~S}$ & TSIA & Sitrat & Lisin & Indol & Ktalase
\end{tabular}

\begin{tabular}{|c|c|c|c|c|c|c|}
\hline & $\begin{array}{l}\mathrm{G} \\
1 \\
\mathrm{u}\end{array}$ & $\begin{array}{l}\mathrm{L} \\
\mathrm{a} \\
\mathrm{k}\end{array}$ & & & & \\
\hline $\mathrm{C}_{1}$ & + & - & + & + & - & + \\
\hline$C_{2}-$ & - & + & + & + & - & + \\
\hline $\mathrm{C}_{3}+$ & - & + & + & + & - & + \\
\hline
\end{tabular}

$\mathrm{C}_{2}$ menunjukkan bakteri yang diduga genus Yersinia sp., dan untuk kode isolat $\mathrm{C}_{3}$ diduga termasuk dalam genus Bacillus $s p$. Identifikasi bakteri dilakukan terhadap isolatisolat yang diperoleh dengan berpedoman pada buku Bergey's Determinative Bacteriology (Holt et al, 1994).

Hasil pengujian ini, untuk uji katalase menunjukkan adanya hasil yang positif untuk ketiga isolat bakteri tersebut, uji katalase bertujuan untuk menentukan kemampuan bakteri dalam mendegradasi hidrogen peroksida $\left(\mathrm{H}_{2} \mathrm{O}_{2}\right)$ melalui produksi enzim. Hasil positif ditandai dengan terbentuknya gelembung-gelembung okseigen yang menunjukkan bahwa organisme yang bersangkutan menghasilkan enzim katalase yang mengubah hydrogen peroksida menjadi air dan oksigen (hadioetomo, 1993).

Pada hasil uji sitrat dengan menggunakan media Simmons Citrate dimana media tersbut merupakan salah satu medium yang digunakan untuk menguji kemampuan bakteri dalam meggunakan sitrat sebagai satusatunya karbon yang digunakan, ketiga isolat menunjukkan hasil yang positif. Menurut Sudarsono, (2008) hasil positif ini ditandai denga adanya perubahan warna medium dari warna hijau menjadi warna biru. Dan untuk uji lysin pada setiap isolat bakteri dengan 
menggunakan media Lysin Iron Agar menunjukkan adanya hasil yang positif hasil positif terdapat pada media yang berwarna lembayung (ungu) (Sarah et al., 2014).

Pada pengujian fermentasi Karbohidrat dengan menggunakan media Triple Sugar Iron Agar (TSIA), media TSIA mengandung tiga macam gula yaitu glukosa, laktosa dan sukrosa. pada uji ini untuk kode isolat $\mathrm{C}_{1}$ terjadi perubahan warnah menjadi warnah merah isolat ini mampu memfermentasikan glukosa, dan untuk kode isolat $\mathrm{C}_{2}$ dan $\mathrm{C}_{3}$ terjadi perubahan warnah menjadi kuning kedua isolat ini mampu memfermentasikan laktosa dan sukrosa. Menurut Sudarsono (2008), uji TSIA ini bertujuan untuk nengetahui kemampuan dari suatu bakteri dalam memfermentasikan gula untuk menghasilkan asam atau gas. Warnah merah pada agar menunjukkan reaksi basa, sedangkan warna kuning menunjukkan reaksi asam. Warna merah pada permukaan agar menunjukkan bahwa terjadinya fermentasi glukosa, dan warna kuning pada bagaian permukaan dan bawah tabung menujukkan terjadinya fermentasi laktosa dan sukrosa.

Hasil dari pengujian $\mathrm{H}_{2} \mathrm{~S}$ yaitu menggunakan media yang sama dengan pengujian Fermentasi Karbohidrat sebelumnya yaitu Triple Sugar Iron Agar (TSIA) dimana media ini mengandung tiga macam gula yaitu glukosa, laktosa dan sukrosa. Hasil pengujian dari ketiga isolat bakteri tersebut dengan kode isolat $\mathrm{C}_{1}$ dan $\mathrm{C}_{2}$ menunjukkan hasil yang negatif dan untuk isolat $\mathrm{C}_{3}$ menujukkan hasil yang positif dilihat dari penelitian menurut Sarah, (2014), hasil uji $\mathrm{H}_{2} \mathrm{~S}$ yang positif menujukkan adanya endapan berwarnah hitam pada dasar (butt) dari media yang digunakan.

Uji indol merupakan uji untuk menentukan kemampuan mikroorganisme dari sampel utnuk menghasilkan indol dari triptofan. Asam amino triptofsn merupakan komponen asam amino yang lazim terdapat dalam protein, sehingga asam amino dengan mudah dapat digunakan oleh mikroorganisme akibat penguraian protein (Sarah et al., 2014). Hasil dari pengujian ini yaitu dengan menggunakan media Nutrient Agar (NA) dari ketiga isolat bakteri yang diuji menunjukkan hasil yang negatif karena tidak terbentuknya cincin berwarna merah setelah penambahan reagen kovac's, sedangkan hasil yang positif adalah sebaliknya.

Pengujian motilitas dari isolat bakteri dengan menggunakan media Nutrient Agar (NA), Motilitas bakteri adalah suatu gerakan dari bakteri yang disebabkan adanya gerakan aktif atau pasif tujuan dari uji ini yaitu untuk mengetahui pergerakan bakteri uji pada media yang ditusuk, dari ketiga isolat bakteri dari sampel Turbinaria ornata, menunjukkan hasil yang negatif. Menurut penelitian dari Sarah et al., (2014) hasil yang negatif dimana pertumbuhan bakteri tidak menyebar dan hanya bertumbuh lurus di daerah tusukan sedangkan hasil yang positif menujukkan pertumbuhan penyebaran bakteri baik disekitar daerah penusukan sampai pada permukaan media.

Identifikasi bakteri pada penelitian ini menggunakan perbandingan pada buku Bergey's Manual Determinative of Bacteriology dan diperoleh 2 genus bakteri yang diduga merupakan Bacillus $S p$. dan Yersinia Sp.

\section{KESIMPULAN}

Berdasarkan hasil penelitian yang telah dilakukan dapat disimpulkan bahwa:

1. Hasil yang diperoleh untuk isolat bakteri dari alga Turbinaria ornata (Turner) J. Agardh, memiliki daya aktivitas antibakteri terhadap bakteri Escherichia coli dan Staphylococcus aureus.

2. Berdasarkan hasil identifikasi secara biokimia isolat $\mathrm{C}_{3}$ diduga termasuk dalam genus Bacillus sp., dan dan isolat $\mathrm{C}_{1}$ dan $\mathrm{C}_{2}$ diduga termasuk dalam genus Yersinia $s p$.

\section{SARAN}

Perlu dilakukan penelitian lebih lanjut pada identifikasi isolat bakteri secara molekuler menggunakan Gen 16S rRNA. 


\section{DAFTAR PUSTAKA}

Dwijoseputro. 1998. Dasar- Dasar Mikrobiologi. Penerbit Djambatan, Jakarta..

Cappucino, J. G., Sherman, N. 1998. Microbiology: A laboratory Manual $5^{\text {th }} \quad$ Edition. California: Benjamin/cummings Science Publishing. P.94.

Davis, W. W., Stout, T. R. 1971. Disc Plate Method of Microbiological Assay. Journal of Microbiology. 22:659665.

Dwijendra I. M., D.S Mewengkang., F.S Mehantow. 2014. Aktivitas Antibakteri dan Karakterisktik Senyawa Fraksi Spons Lamellodysidea Herbacae Yang Diperoleh Dari Teluk Manado. Pharmacon Jurnal Ilmiah Farmasi. 4:2302-2493.

Hadioetomo R. S. 1993. Mikrobiologi Dasar Dalam Praktek. PT. Gramedia, Jakarta.

Harmawan, A., A, ridho., D, pringgenies. 2012. Uji Fitokimia dan Aktifitas Anti Bakteri Ekstrak Media Supernatan Bakteri Simbion Vibrio sp. Gastropoda Oliva vidua Terhadap Bakteri Multi Drug Resistant. Universitas Diponegoro Kampus Tembalang. Semarang.

Hudayanti, M. 2004. Aktivitas antibakteri rimpang temulawak (Curcuma xanthorrihza roxb), Skripsi jurusan kimia, Institut pertanian bogor, Bogor. Hal: 6, 8-9, 21.

Laksanawati, R., Ustadi., A. Husni. 2017. pengembangan metode ekstraksi alginat dari rumput laut turbinaria ornate.

Lay, B. W. 1994. Analisis Mikroba di laboratorium.Edisi 1. Raja Grafindo Persada, Jakarta.
Lenni, F., and Yekki Y. 2011. Isolasi dan Pengamatan Morfologi Koloni Bakteri Kinolitik. Jurnal Ilmiah Pendidikan Biologi. 3:2.

Ngajow, M., Abidjulu, J., Vanda S.K. 2013. Pengaruh anntibakteri ekstrak kulit batang matoa (Pometia pinnata) terhadap bakteri Staphylococcus aureus secara invitro. Jurnal Mipa Unsrat 2(2) 128-132.

Sarah M.P., Fatimawali., Aaltje M. 2014. Identifikasi Bkateri Resisten Merkuri Pada Urine Feses dan Kalkulus Gigi Pada Individu Di Kecamatan Malalayang, Manado, Sulawesi Utara. Jurnal e-Biomedik. 2(2): 532540.

Satari, R. 1996. Potensi Pemanfaatan Rumput Laut Indonesia. Pusat Penelitian dan Pengembangan Oseanologi LIPI, Jakarta. 152-177.

Sudarsono A. 2008. Isolasi dan karakterisasi Bakteri pada ikan laut dalam Spesies ikan Gindara (Lepidocibium Flavobronneum). Skripsi. Institut Pertanian Bogor, Bogor.

Sumardjo, D. 2009. Pengantar Kimia. Buku Kedokteran EGC. Jakarta.

Taslihan, A. 2001. Cara Isolasi dan Identifikasi Bakteri dari Air, Ikan dan Udang di Air Payau. $B B P B A P$. Jepara.

Vijayabaskar P., V. Shiyamala. 2011. Antibacterial Activities of Brown Marine Algae (Sargassum wightii and Turbinaria ornata) from the Gulf of Mannar Biosphere Reserve. 